\title{
Four new species of the millipede genus Eutricbodesmus Silvestri, 1910, from caves in Indochina (Diplopoda: Polydesmida: Haplodesmidae)
}

\section{Четыре новых вида диплопод рода Eutrichodesmus Silvestri, 1910 из пещер Индокитая (Diplopoda: Polydesmida: Haplodesmidae)}

\author{
S.I. Golovatch ${ }^{1}$, J.-J. Geoffroy ${ }^{2}$, J.-P. Mauriès ${ }^{3}$, D. VandenSpiegel ${ }^{4}$ \\ С.И. Головач ${ }^{1}$, Ж.-ЖК. ЖКоффруа ${ }^{2}$, Ж.-П. Морьес ${ }^{3}$, \\ А. ВанденШпигель ${ }^{4}$
}

\footnotetext{
${ }^{1}$ Institute for Problems of Ecology and Evolution, Russian Academy of Sciences, Leninsky pr. 33, Moscow 119071 Russia; e-mail: sgolovatch@yandex.ru

Институт проблем экологии и эволюции РАН, Ленинский пр., 33, Москва 119071 Россия.

${ }^{2}$ Muséum national d'Histoire naturelle, DSE, Site MNHN de Brunoy, 4 avenue du petit Château, 91800 Brunoy, France.

${ }^{3}$ Muséum national d'Histoire naturelle, Département Systématique \& Evolution, CP n53, 61 rue Buffon, 75005 Paris, France.

${ }^{4}$ Muséum Royal de l’Afrique Centrale, Tervuren, B-3080 Belgium.
}

KEY WORDS: Diplopoda, Eutrichodesmus, new species, cave, Vietnam, Laos.

КЛЮЧЕВЫЕ СЛОВА: Diplopoda, Eutrichodesmus, новый вид, пещера, Вьетнам, Лаос.

ABSTRACT. Four new species are described in the large genus Eutrichodesmus Silvestri, 1910, which ranges from southern Japan in the north, through Taiwan, southern China and Indochina, to Vanuatu, Melanesia in the south: E. nadan sp.n., from a cave in Laos, as well as E. astrisimilis sp.n., E. subasteroides sp.n. and E. astriproximus sp.n., all three from caves in Vietnam.

РЕЗЮМЕ. В большом роде Eutrichodesmus Silvestri, 1910, который распространен от Южной Японии на севере, через Тайвань, Южный Китай и Индокитай, до Вануату (Меланезия) на юге, описаны четыре новых вида: E. nadan sp.n., из пещеры в Лаосе, а также E. astrisimilis sp.n., E. subasteroides sp.n. и E. astriproximus sp.n., все три из пещер Вьетнама.

\section{Introduction}

The millipede family Haplodesmidae Cook, 1895, which has only seven component genera basically occurring (except for a few pantropical introductions) in South, East and Southeast Asia, as well as the southwestern Pacific region and Australia, has recently been reviewed [Golovatch et al., 2009a, b, 2010; Golovatch, VandenSpiegel, 2014]. The most speciose genus is Eutrichodesmus Silvestri, 1910, which currently contains 45 described species, largely cavernicoles, and ranges from southern Japan in the north, through Taiwan, southern China and Indochina, to Vanuatu, Melanesia in the south [Golovatch et al., 2015].
The present paper puts on record another four new cavernicolous species of Eutrichodesmus, including one from Laos and three from Vietnam.

\section{Material and methods}

The material serving as the basis for the present contribution derives from subterranean collections made in 2011 in Laos and Vietnam by Louis Deharveng and Anne Bedos, both from the Muséum national d'Histoire naturelle (MNHN), Paris, France. Most of the material, including all holotypes, has been deposited in MNHN, with only two samples shared with the collection of the Zoological Museum, State University of Moscow (ZMUM), Moscow, Russia. The term "doratodesmoid" is used hereafter only in its vernacular meaning, in order to concisely characterize a body shape, i.e. capable or nearly capable of volvation. SEM micrographs were taken using a JEOL JSM-6480LV scanning electron microscope. After examination, SEM material was removed from stubs and returned to alcohol, all such samples being kept at MNHN.

\section{Species descriptions}

Eutrichodesmus nadan sp.n.

Figs $1 \& 2$.

HOLOTYPE $0^{7}$ (MNHN JC379), Laos, Khammouane Prov, Ban Nadan, Cave Tham Nadan, N17.708476 ${ }^{\circ}$, E105.021793, 270 m a.s.1., 11.XI.2011, leg. L. Deharveng \& A. Bedos (Lao11-53).

PARATYPES: 1 O (MNHN JC379), 1 \% (SEM), same place, together with holotype. 

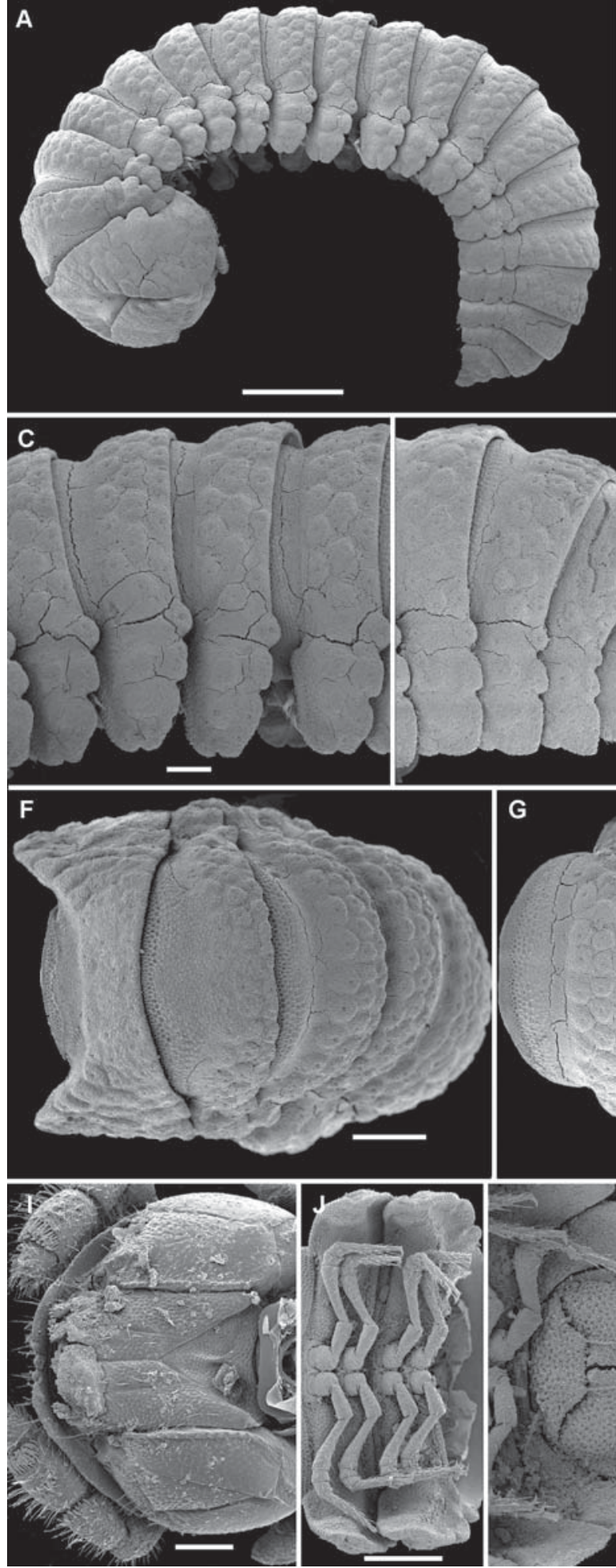

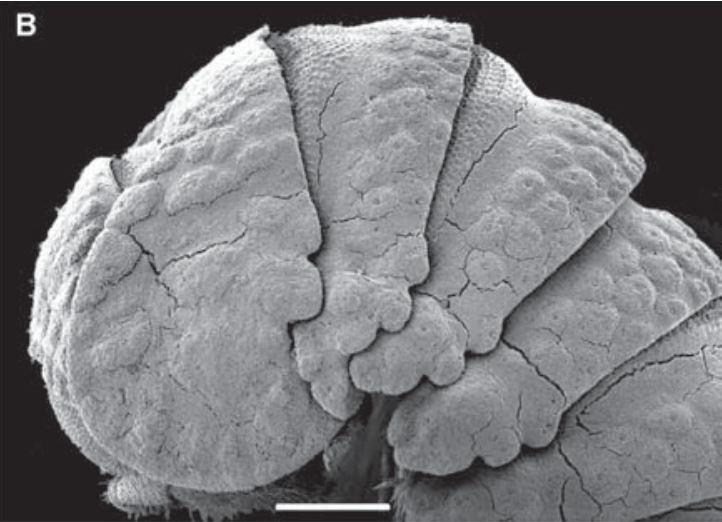

D
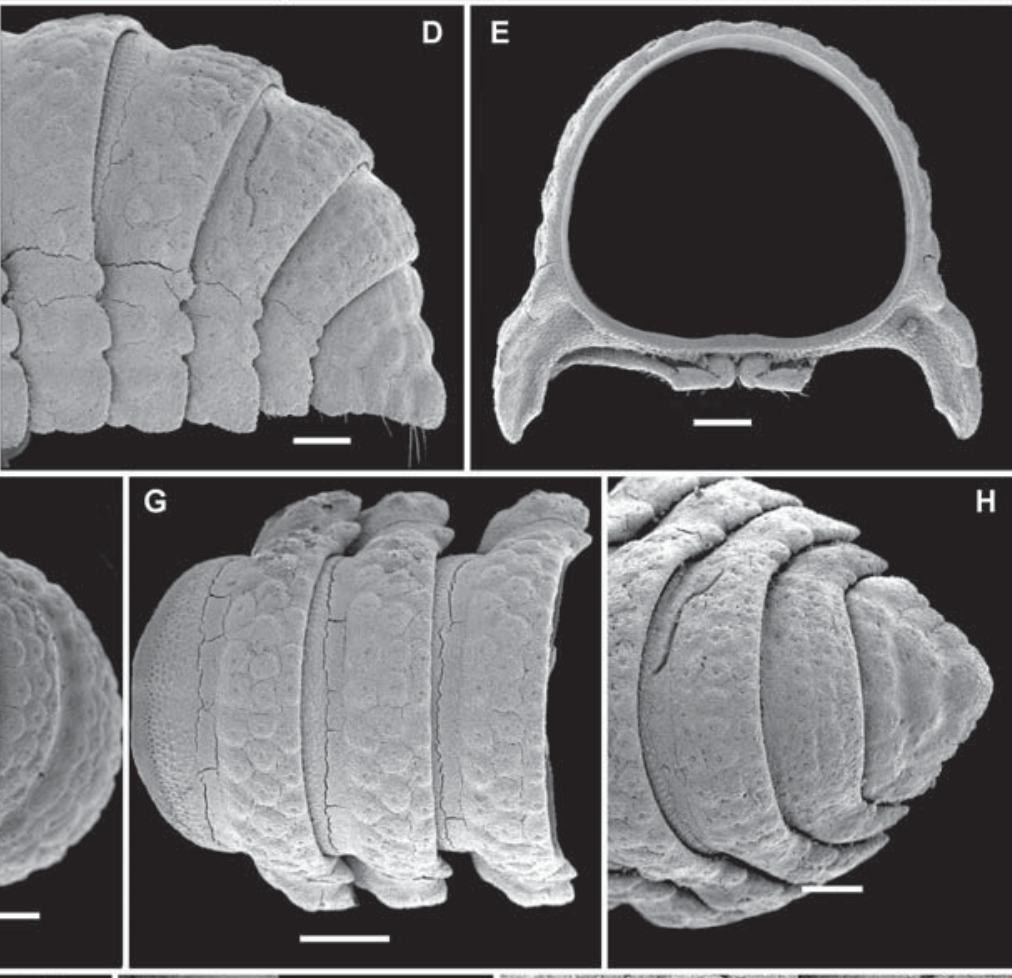

H
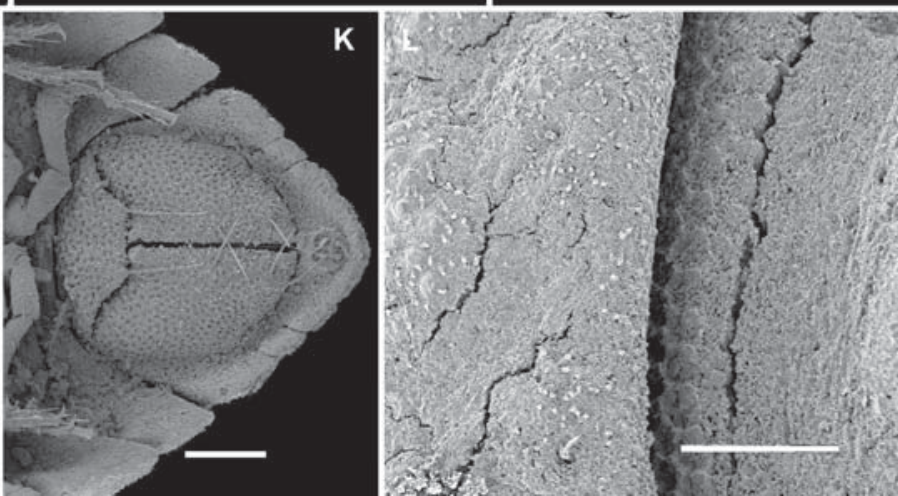

Fig. 1. Eutrichodesmus nadan sp.n., $\sigma^{7}$ paratype. A - habitus, lateral view; B \& F — anterior part of body, lateral and dorsal views, respectively; C, G \& J - midbody segments, lateral, dorsal and ventral views, respectively; D, H \& K — posterior part of body, lateral, dorsal and ventral views, respectively; E - cross-section of a midbody segment, caudal view; I - head, ventral view; L - fine structure of tegument, dorsal view. Scale bars: 0.5 (A), 0.2 (B, F, G \& J), 0.1 (C-E, H, I \& K) \& 0.02 mm (L).

Рис. 1. Eutrichodesmus nadan sp.n., паратип О7. А - общий вид, сбоку; В и F - передняя часть тела, соответственно сбоку и сверху; C, G и J - среднетуловищные сегменты, соответственно сбоку, сверху и снизу; D, H и K - задняя часть тела, соответственно сбоку, сверху и снизу; Е - поперечный разрез среднетуловищного сегмента, сзади; I - голова, снизу; L микроструктура покровов. Масштаб: 0,5 (A), 0,2 (B, F, G и J), 0,1 (C-E, H, I и K) и 0,02 мм (L). 
NAME. To emphasize the provenance from Cave Nadan; noun in apposition.

DIAGNOSIS. Differs in the obliterated metatergal tuberculation represented by three transverse rows of subequal, round, setigerous bosses, coupled with laterally bilobate, short and strongly declivous paraterga (apparently ensuring perfect volvation), as well as by a few minor details of gonopod structure (in particular, the shape of the telopodite).

DESCRIPTION. Length of adults of both sexes ca $5.0 \mathrm{~mm}$, width $1.0 \mathrm{~mm}$, body broadest at segment 3 or 4. Coloration uniformly light creamy brown. Adults with 20 segments, body subcylindrical, conglobation complete (Fig. 1A-H, J, K). Head (Fig. 1I) slightly transverse (wider than high), rather densely pilose, microgranular and microvillose just below antennae and on vertex; isthmus between antennal sockets about as wide as diameter of antennal socket. Antennae (Fig. 1I) rather long and slender; antennomere 6 longer than 5, both with an evident dorso-apical pit containing a tight group of minute bacilliform sensilla; antennomere 8 with the usual four sensory cones apically. Collum rather large, broader than head, distinctly flattened medially near front margin, not covering the head from above; entire surface microvillose, with a few transverse rows of very flat round bosses. Prozona very finely alveolate, collum and metaterga covered with a cerategumental crust held by abundant microvilli; stricture between pro- and metazona broad and shallow, more finely alveolate-microgranular than prozona. Limbus microcrenulate, partly hidden by nearby abundant microvilli (Fig. 1L). Metaterga 2-19 subequal in height, with three transverse, mixostictic (i.e. irregular in axial direction) and strongly obliterated rows of subequal, very flat, round, setigerous bosses (Fig. 1A-H). Paraterga very strongly declivous, rather broad and short, bilobate laterally, evidently surpassing level of venter, caudolaterally at base usually with another two distinct lobulations (Fig. 1A-D); middle and, especially, posterior parts of body set off laterally at base by a distinct impression, thus somewhat interrupting contour of convex dorsum; paraterga 2 strongly enlarged, anterolateral margins regularly rounded, without distinct lobulation, schism and hyposchism both very small; paraterga 4 slightly shorter than others (Fig. 1A, B), overlap of following paraterga typical. Pore formula normal (5, $7,9,10,12,13,15-19)$, ozopores indistinct, located above base of caudolateral lobulation. Metatergal setation very short and inconspicuous (Fig. 1L). Pleurotergal ridges absent. Epiproct short, also with flat bosses dorsally and a few indistinct lobulations at lateral margin, directed ventrocaudad, with the usual four cones just below tip (Fig. 1D, H, K). Hypoproct and paraprocts normal (Fig. 1K).

Sterna usually with a deep, narrow, transverse depression between coxae (Fig. 1J), only sterna between $\sigma^{7}$ coxae 6, 7 and 9 much wider. Gonopod aperture suboval, relatively small, far from reaching lateral sides of segment 7. Legs rather long and relatively slender, barely overreaching tips of paraterga; femoral and tar-

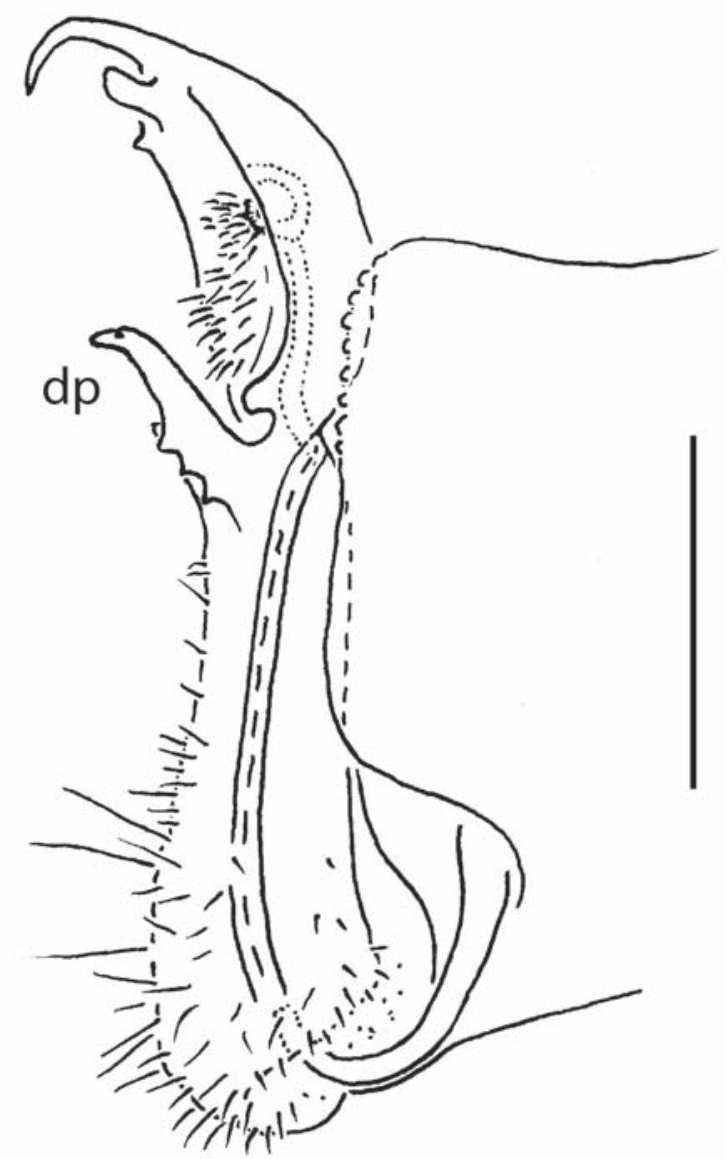

Fig. 2. Eutrichodesmus nadan sp.n., $\bigcirc^{7}$ paratype, right gonopod, mesal view. Scale bar: $0.1 \mathrm{~mm}$.

Рис. 2. Eutrichodesmus nadan sp.n., паратип О7, правый гонопод, изнутри. Масштаб: 0,1 мм.

sal segments longest, subequal in length; claw normal, simple, very slightly curved ventrad (Fig. 1J).

Gonopods (Fig. 2) simple. Coxae subquadrate, large, microtuberculate and poorly setose ventrolaterally, with a conspicuous triangular lobe frontolaterally. Telopodite somewhat longer than coxite, slender throughout, setose in its basal half, with a conspicuous, denticulate, lateral, distofemoral process (dp) at about midway; tip of telopodite subunciform, with a small, mesal, subapical lobule; seminal groove terminating distally inside an evident accessory seminal chamber, the latter's orifice furnished with a conspicuous hairy pulvillus.

REMARKS. This light and small species shows no differentiation of metatergal bosses, coupled with a highly inconspicuous tergal setation. It is a typical "doratodesmid" (capable of volvation, see Golovatch et al. [2009a, b]), possibly a troglobite.

\section{Eutrichodesmus astrisimilis sp.n.} Figs $3 \& 4$.

HOLOTYPE O (MNHN JC380), Vietnam, Quang Binh Prov.,

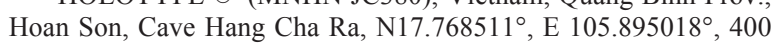
m a.s.1., 21.XI.2011, leg. L. Deharveng \& A. Bedos (Vn11-40). 


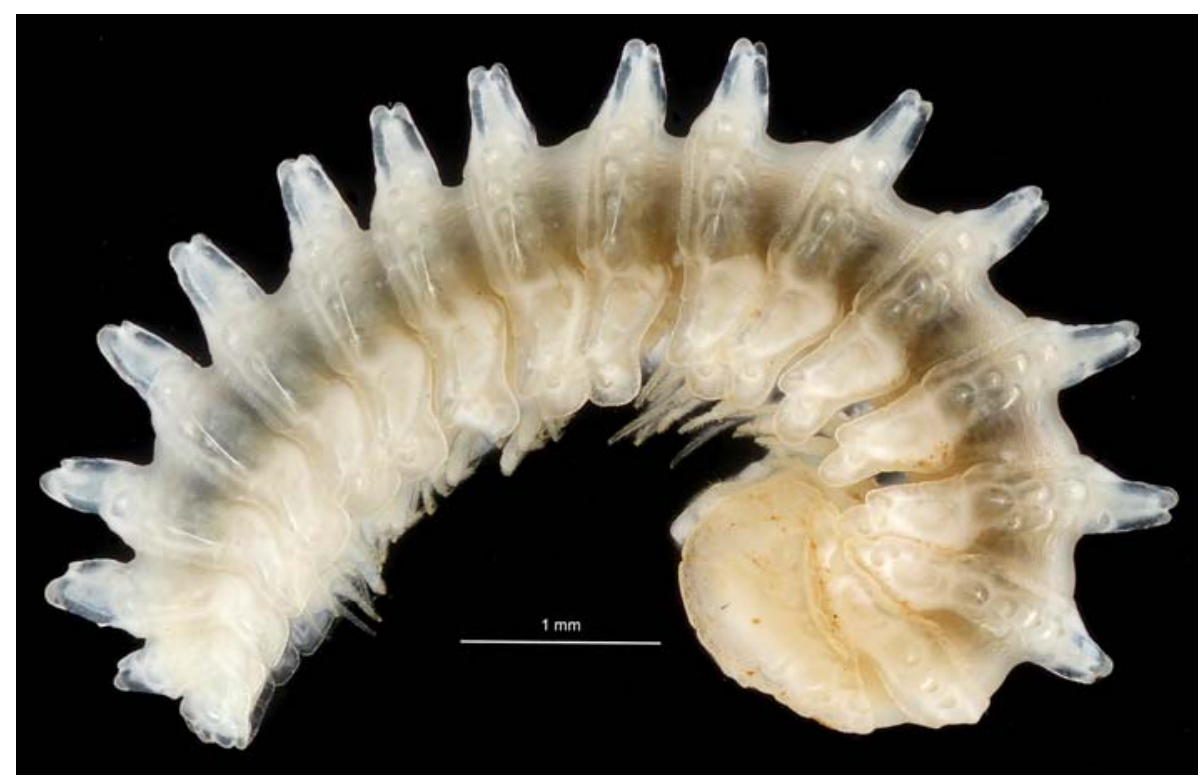

Fig. 3. Eutrichodesmus astrisimilis sp.n., $O^{7}$ holotype, habitus, lateral view. Picture by D. VandenSpiegel.

Pис. 3. Eutrichodesmus astrisimilis sp.n., голотип О7, общий вид, сбоку. Фотография D. VandenSpiegel.

PARATYPES: $1 \bigcirc^{7}$ (MNHN JC380), 1 (SEM), same place, together with holotype.

NAME. To emphasize the similarity to E. aster Golovatch, Geoffroy, Mauriès et VandenSpiegel, 2009 or E. asteroides Golovatch, Geoffroy, Mauriès et VandenSpiegel, 2009; adjective.

DIAGNOSIS. Differs from the superficially most similar E. asteroides, also a cavernicole from Quang Binh Province [Golovatch et al., 2009b], chiefly in gonopod structure, i.e. the suberect telopodite, most of which is taken up by the setose prefemoral part, as well as the finger-shaped $\mathbf{d p}$ and an unusually short acropodite represented by a mesal velum and a short, but slender lateral branch with a subapical hairy pulvillus at the latter's base.

DESCRIPTION. Length of adults of both sexes ca 8.0 ( $\sigma^{7}$ holotype) to $9.0 \mathrm{~mm}$ ( $\odot$ paratypes), width 2.0 ( $\sigma^{7}$ holotype) to $2.2 \mathrm{~mm}$ ( $q$ paratypes), body broadest at segment 3 or 4 . Coloration uniformly pallid to light creamy brown.

All characters as in E. nadan sp.n., except as follows (Figs 3 \& 4).

Adults with 19 segments, body asteroid, conglobation complete (Figs 3 \& 4A-K). Head (Fig. 4G) slightly transverse (wider than high), densely pilose, microgranular and microvillose just below antennae and on vertex; isthmus between antennal sockets about as 1.2 times as wide as diameter of antennal socket. Antennae (Fig. 4G) rather long and slender, only slightly clavate. Collum rather large, broader than head, crescent-shaped, not covering the head from above; entire surface microvillose, with several transverse rows of round tubercles, lobulate at fore margin. Following metaterga with three transverse mixostictic (i.e. irregular in axial direction) rows of $5+5$ clearly differentiated, mostly round, setigerous tubercles, central $1+1$ in fore and middle rows being considerably higher on segments $5-17$, only slightly shorter on segments 4 and 18 (Figs 3 \& 4A-F). Paraterga strongly declivous, directed ventrolaterad at about $45^{\circ}$, broad and long, unilobate laterally, evidently surpassing level of venter, caudolaterally at base with one particularly large and another few indistinct lobulations extending across dorsum and forming rear metatergal row of lobulations (Figs $3 \& 4 \mathrm{~A}-\mathrm{F}$ ); paraterga set off laterally at base by a distinct impression, thus somewhat interrupting contour of convex dorsum; paraterga 2 strongly enlarged, anterolateral margins regularly rounded, with several indistinct lobulations, schism and hyposchism both very small; paraterga 4 slightly shorter than others (Figs $3 \& 4$ A), overlap of following paraterga typical. Pore formula apparently normal, but ozopores barely visible, located above base of lateral lobulation. Metatergal setation fully abraded/ missing. Epiproct short, also with several evident tu-

Fig. 4. Eutrichodesmus astrisimilis sp.n., † paratype (A-K) \& $\sigma^{7}$ holotype (L). A, D \& G - anterior part of body, lateral, dorsal and ventral views, respectively; B, E \& H - midbody segments, lateral, dorsal and ventral views, respectively; C, F \& I - posterior part of body, lateral, dorsal and ventral views, respectively; J - cross-section of a midbody segment, caudal view; K - fine structure of tegument, dorsal view; L - left gonopod, mesal view. Scale bars: 0.5 (A, B, D-G \& J), 0.2 (C, H, I \& L) \& 0.05 mm (K).

Рис. 4. Eutrichodesmus astrisimilis sp.n., паратип + (A-K) и голотип $\sigma^{7}(\mathrm{~L})$. A, D и G - передняя часть тела, соответственно сбоку, сверху и снизу; В, Е и Н - среднетуловищные сегменты, соответственно сбоку, сверху и снизу; C, F и I — задняя часть тела, соответственно сбоку, сверху и снизу; J - поперечный разрез среднетуловищного сегмента, сзади; K - микроструктура покровов, сверху; L — левый гонопод, изнутри. Масштаб: 0,5 (A, B, D-G и J), 0,2 (C, H, I и L), и 0,05 мм (K). 

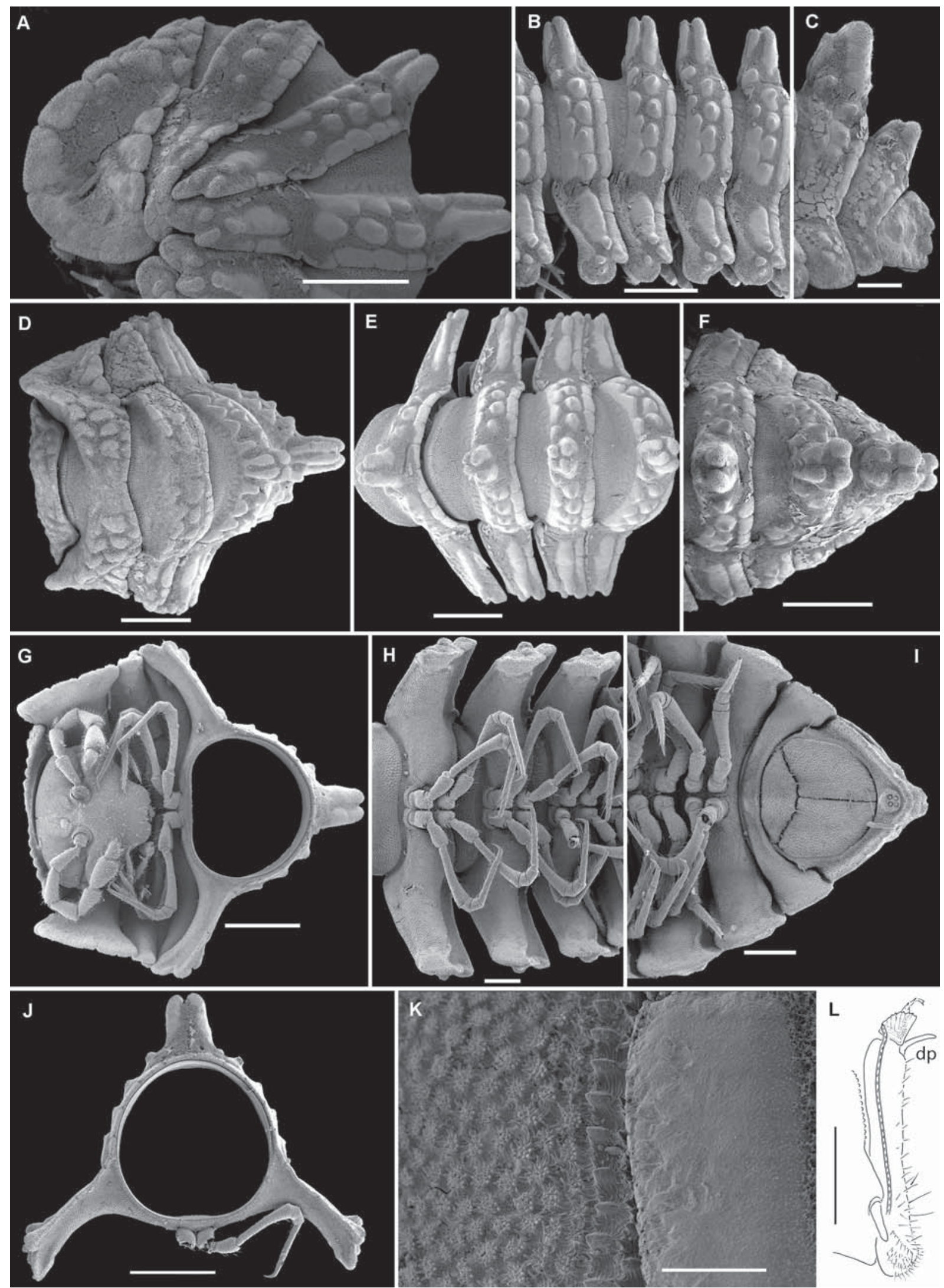

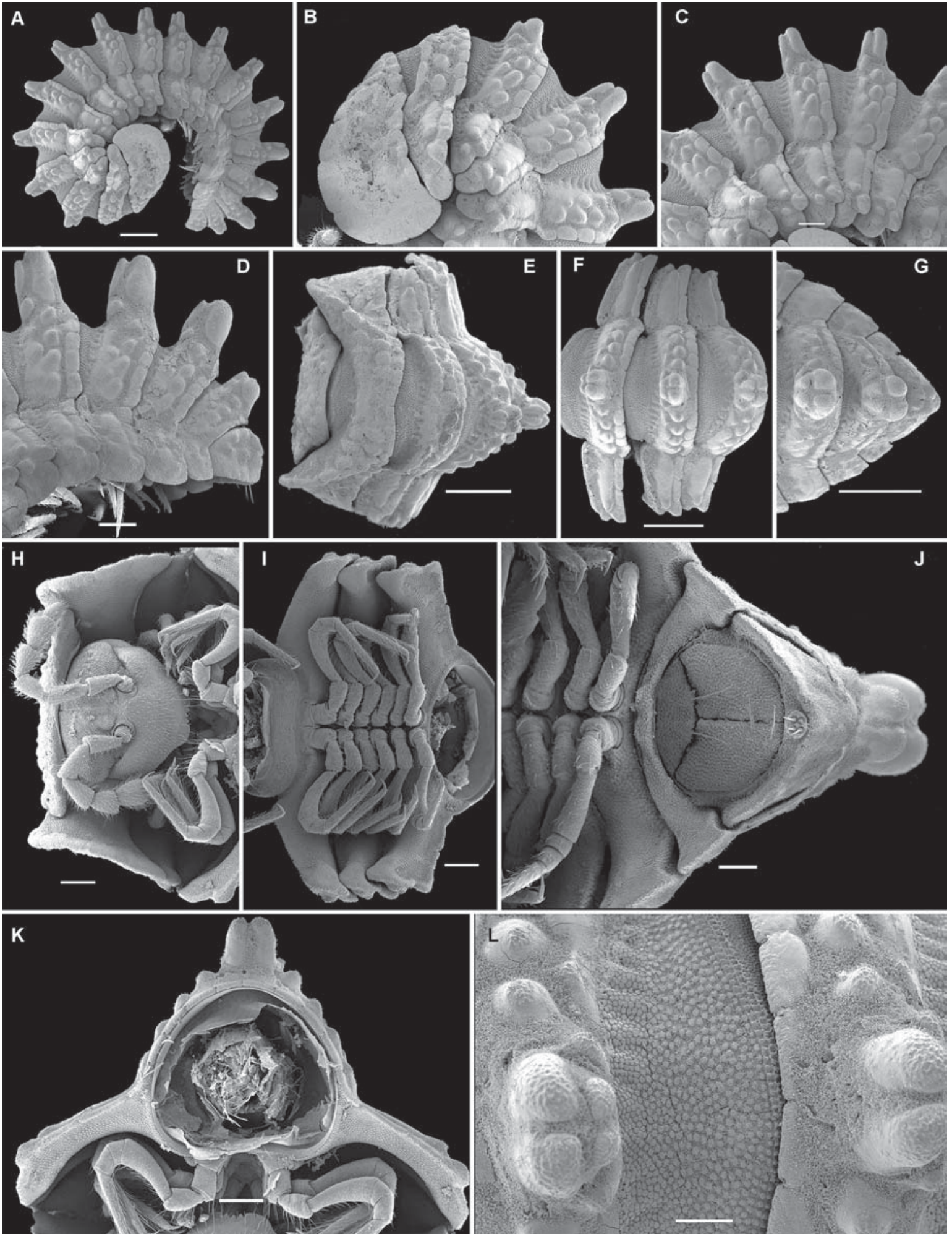

Fig. 5. Eutrichodesmus subasteroides sp.n., O paratype. A - habitus, lateral view; B, E \& H - anterior part of body, lateral, dorsal and ventral views, respectively; C, F \& I — midbody segments, lateral, dorsal and ventral views, respectively; D, G \& J — posterior part of body, lateral, dorsal and ventral views, respectively; $\mathrm{K}$ - cross-section of a midbody segment, caudal view; L — fine structure of tegument, dorsal view. Scale bars: 0.5 (A, E-G), 0.2 (B-D, H, I \& K) \& $0.1 \mathrm{~mm}(\mathrm{~J} \& \mathrm{~L})$.

Рис. 5. Eutrichodesmus subasteroides sp.n., паратип О’. А - общий вид, сбоку; В, Е и Н - передняя часть тела, соответственно сбоку, сверху и снизу; C, F и I - среднетуловищные сегменты, соответственно сбоку, сверху и снизу; D, G и J - задняя часть тела, соответственно сбоку, сверху и снизу; $\mathrm{K}$ - поперечный разрез среднетуловищного сегмента, сзади; L - микроструктура покровов, сверху. Масштаб: 0,5 (A, E-G), 0,2 (B-D, H, I и K), и 0,1 мм (J и L). 

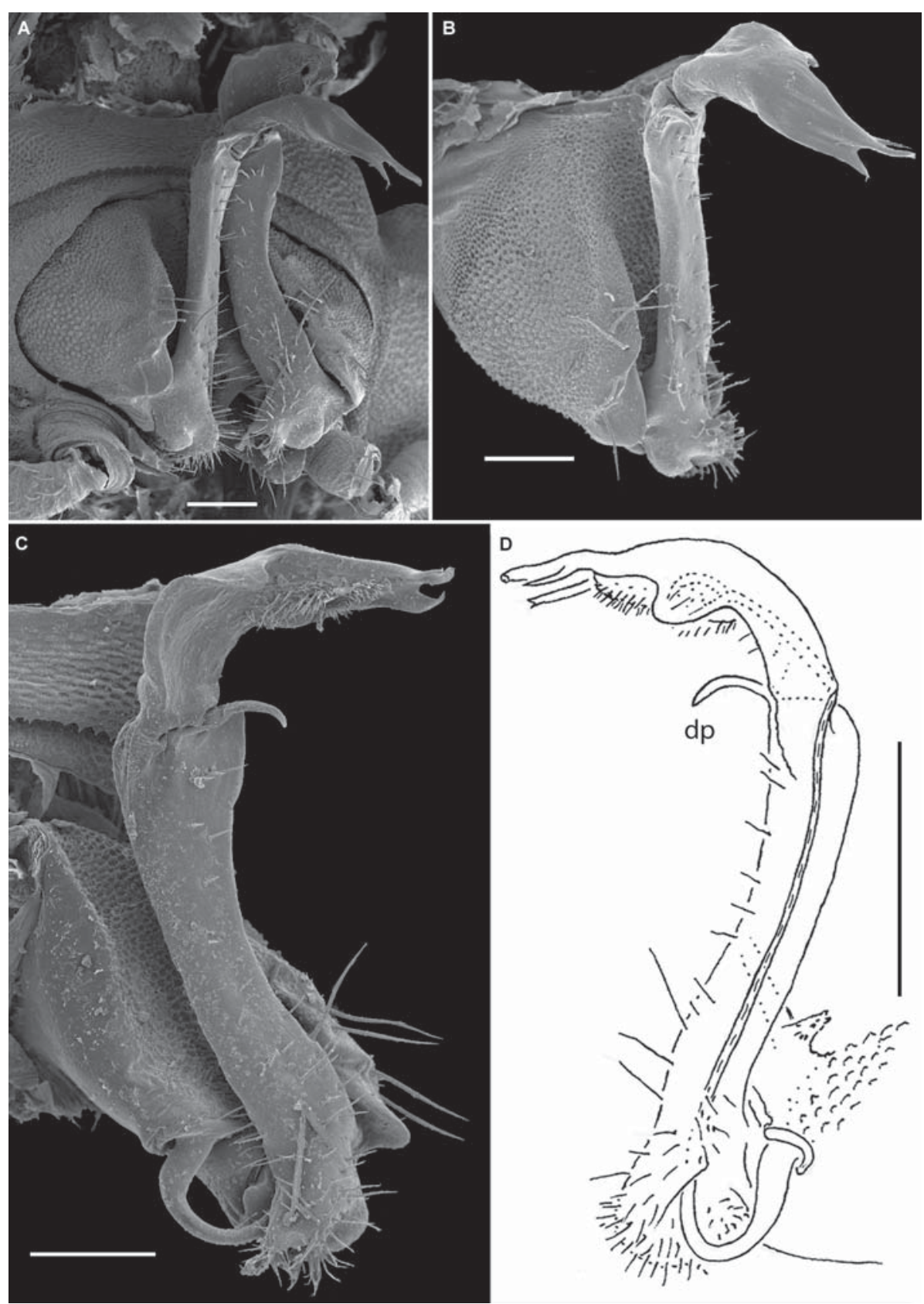

Fig. 6. Gonopods of Eutrichodesmus subasteroides sp.n., O paratypes. A - both gonopods in situ, subventral view; B \& D - right gonopod, sublateral and mesal views, respectively; C - left gonopod, mesal view. Scale bars: 0.2 (D) \& $0.1 \mathrm{~mm}$ (A-C).

Рис. 6. Гоноподы Eutrichodesmus subasteroides sp.n., паратипы O’. А — оба гонопода на месте, почти снизу; В и D — правый гонопод, соответственно почти сбоку и изнутри; C — левый гонопод, изнутри. Масштаб: 0,2 (D) и 0,1 мм (A-C).

bercles dorsally and a few indistinct lobulations at lateral margin, directed ventrocaudad, with the usual four cones just below tip (Fig. 4C, F, I).

Legs rather long and relatively slender, barely overreaching tips of paraterga; femoral and tarsal segments longest, subequal in length (Fig. 4G-I).

Gonopods (Fig. 4L) simple. Telopodite somewhat longer than coxite, slender throughout, suberect; prefemoral (= densely setose) part taking up most of telopodite; distofemoral process (dp) a small finger; tip of te- lopodite with a small, mesal, fringed velum and only slightly longer, also fringed, slender, lateral, apical branchlet with a distinct hairy pulvillus at base; seminal groove terminating subapically inside an unusually small accessory seminal chamber.

REMARKS. This pallid species shows a marked differentiation of metatergal tubercles ensuring an asteroid appearance, coupled with a wanting tergal setation. This is a typical "doratodesmid" (capable of volvation, see Golovatch et al. [2009a, b]), likely a troglobite. 

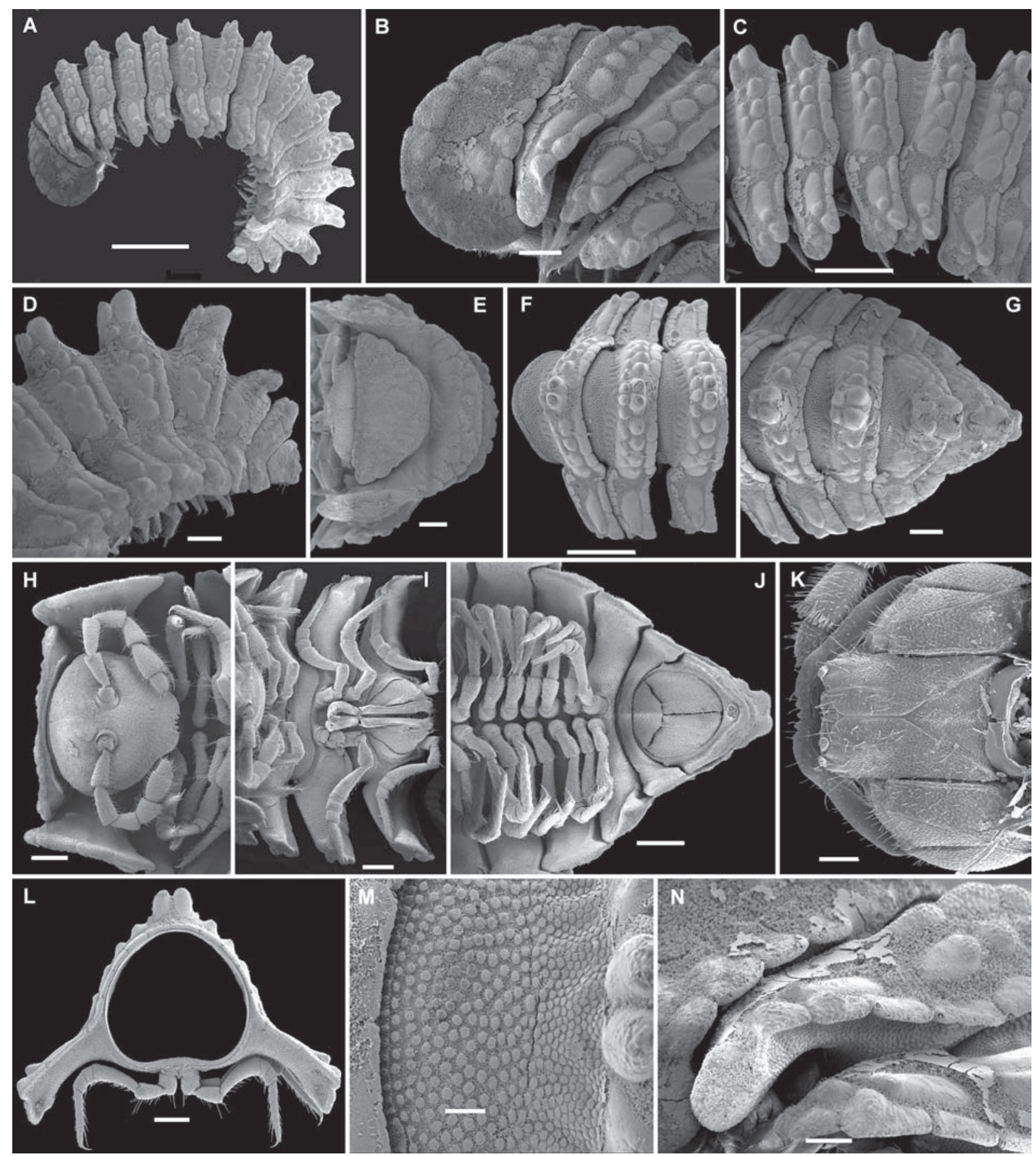

Fig. 7. Eutrichodesmus astriproximus sp.n., O' paratype. A - habitus, lateral view; B, E \& H - anterior part of body, lateral, dorsal and ventral views, respectively; C, F \& I - midbody segments, lateral, dorsal and ventral views, respectively; D, G \& J - posterior part of body, lateral, dorsal and ventral views, respectively; $\mathrm{K}$ - head, ventral view; $\mathrm{L}$ - cross-section of a midbody segment, caudal view; M fine structure of tegument, dorsal view; $\mathrm{N}$ - parts of paraterga 2-4, lateral view. Scale bars: 1.0 (A), 0.5 (C \& F), 0.2 (B, D, E, G-L), 0.1 (N) \& $0.05 \mathrm{~mm}(\mathrm{M})$

Рис. 7. Eutrichodesmus astriproximus sp.n., паратип О’. А - общий вид, сбоку; В, Е и Н - передняя часть тела, соответственно сбоку, сверху и снизу; C, F и I - среднетуловищные сегменты, соответственно сбоку, сверху и снизу; D, G и J - задняя часть тела, соответственно сбоку, сверху и снизу; K — голова, снизу; L — поперечный разрез среднетуловищного сегмента, сзади; M микроструктура покровов, сверху; $\mathrm{N}$ - части паратергитов 2-4, сбоку. Масштаб: 1,0 (A), 0,5 (C и F), 0,2 (B, D, E, G-L), 0,1 (N) и 0,05 мм $(\mathrm{N})$ 

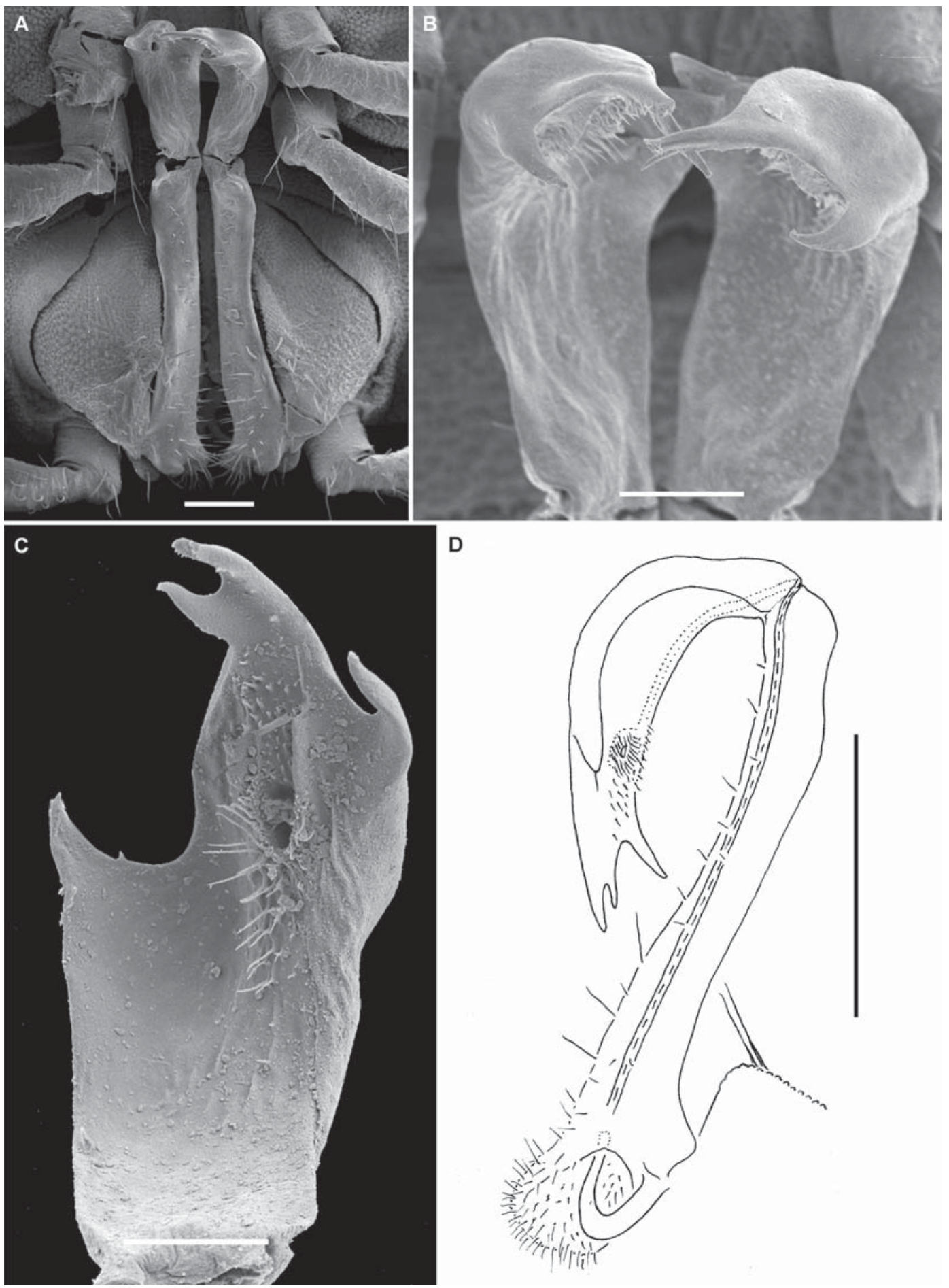

D



Fig. 8. Gonopods of Eutrichodesmus astriproximus sp.n., $\sigma^{7}$ paratype (A-C) \& $\sigma^{7}$ holotype (D). A - both gonopods in situ, ventral view; B - distal parts of both gonopods in situ, ventral view; C — distal part of left gonopod, caudoventral view; D - right gonopod, mesal view. Scale bars: 0.2 (D), $0.1 \mathrm{~mm}(\mathrm{~A}) \& 0.05 \mathrm{~mm}$ (B \& C).

Рис. 8. Гоноподы Eutrichodesmus astriproximus sp.n., паратип Оج (A-C) и голотип О’ (D). А — оба гонопода на месте, снизу; В дистальные части обоих гоноподов на месте, снизу; C - дистальная часть левого гонопода, одновременно сзади и снизу; D правый гонопод, изнутри. Масштаб: 0,2 (D), 0,1 (A) и 0,05 мм (В и C). 


\section{Eutrichodesmus subasteroides sp.n.}

Figs 5 \& 6.

HOLOTYPE $0^{7}$ (MNHN JC381), Vietnam, Quang Binh Prov., Hoan Son, Cave Hang Da Voi, N17.758800 ${ }^{\circ}$, E105.892121 ${ }^{\circ}$, ca 370 m a.s.1., 22.XI.2011, leg. L. Deharveng \& A. Bedos (Vn11-46).

PARATYPES: $2 \sigma^{7} \sigma^{7}, 13$ 우, 6 juv. (MNHN JC381), $10^{7}, 1$ (ZMUM $\rho 3163$ ), $1 \sigma^{\top}$ (SEM), same place, together with holotype.

NAME. To again emphasize the similarity to $E$. aster or E. asteroides; adjective.

DIAGNOSIS. Very similar to E. astrisimilis sp.n. (see above), but differs clearly in gonopod structure, in particular a trifid tip of the telopodite.

DESCRIPTION. Length of adults of both sexes ca 8.0-9.0 mm $\left(\sigma^{\top},+\right)$, width 2.0-2.4 mm $\left(\sigma^{\top},+\right)$, body broadest at segment 3 or 4 . Coloration uniformly pallid to light creamy brown.

All characters as in E. astrisimilis sp.n., except as follows (Figs 5 \& 6).

Gonopods (Fig. 6) simple. Telopodite somewhat longer than coxite, slender throughout, suberect; prefemoral (= densely setose) part taking up most of telopodite; distofemoral process (dp) a small finger; a rounded mesal lobule and a very distinct hairy pulvillus basal to a trifid tip of telopodite; seminal groove terminating subapically inside a small, but evident accessory seminal chamber.

REMARKS. Like E. astrisimilis sp.n., this pallid species shows a marked differentiation of metatergal tubercles, coupled with a wanting tergal setation. This is also a typical "doratodesmid" (capable of volvation, see Golovatch et al. [2009a, b]), likely a troglobite.

\section{Eutrichodesmus astriproximus sp.n.} Figs $7 \& 8$.

HOLOTYPE Oフ (MNHN JC382), Vietnam, Quang Binh Prov., Thuong Hoa, Cave Hang Mo O, N17.668089 , E105.939839², 335 $\mathrm{m}$ a.s.1., 24.XI.2011, leg. L. Deharveng \& A. Bedos (Vn11-52).

PARATYPES: 9 OO, 4 juv. (MNHN JC382), $1 \sigma^{\top}$ (SEM), same place, together with holotype.

NAME. To again emphasize the similarity to $E$. aster or E. asteroides; adjective.

DIAGNOSIS. Very similar to E. astrisimilis sp.n. (see above), also in sharing a trifid tip of the gonopod telopodite, but the subapical mesal lobule is rather dentiform, the apical branchlets slightly differently shaped while a distofemoral process is virtually absent.

DESCRIPTION. Length of adults of both sexes ca 8.0-9.0 mm $\left(\sigma^{\top},+\right)$, width 2.0-2.4 mm $\left(\sigma^{\top},+\right)$, body broadest at segment 3 or 4 . Coloration uniformly pallid to light creamy brown.

All characters as in E. astrisimilis sp.n., except as follows (Figs $7 \&$ 8).
Gonopods (Fig. 8) simple. Telopodite somewhat longer than coxite, clearly subgeniculate; prefemoral (= densely setose) part taking up much of telopodite; distofemoral process absent; a distomesal tooth and a smaller hairy pulvillus basal to a trifid tip of telopodite; seminal groove terminating subapically inside a small accessory seminal chamber.

REMARKS. Like E. astrisimilis sp.n., this pallid species shows a marked differentiation of metatergal tubercles, coupled with a wanting tergal setation. This is also a typical "doratodesmid" (capable of volvation, see Golovatch et al. [2009a, b]), likely a troglobite as well.

ACKNOWLEDGEMENTS. The first author is most grateful to the Administration of the Muséum national d'Histoire naturelle, Paris, France, for the financial support rendered during his visit to MNHN in April 2016. We are also greatly obliged to Louis Deharveng and Anne Bedos (both MNHN) for the precious material they provided for our study. The Vietnamese species were collected during their 2011 survey of cave invertebrates in the Phong Nha-Ke Bang National Park, as part of the project "Nature Conservation and Sustainable Natural Resource Management in the Phong Nha-Ke Bang Region, Vietnam", funded by the German development bank KfW. The Laotian species was collected during their 2011 project "Fragmentation des karsts et diversification des faunes associées dans le massif karstique Khammouane-Kebang (Laos et Vietnam)", headed by L. Deharveng and funded by the MNHN ATM (Action Transversale Muséum) "Biodiversité actuelle et fossile - Crises, stress, restaurations et panchronismes: le message systématique".

\section{References}

Golovatch S.I., VandenSpiegel D. 2014. Koponenius gen. nov., a new genus of the millipede family Haplodesmidae from the Himalayas of India and Nepal (Diplopoda: Polydesmida) // Zootaxa. Vol.3894. No.1. P.141-151.

Golovatch S.I., Geoffroy J.-J., Mauriès J.-P., VandenSpiegel D. 2009a. Review of the millipede family Haplodesmidae Cook, 1895 , with descriptions of some new or poorly-known species (Diplopoda, Polydesmida) // ZooKeys. Vol.7. P.1-53.

Golovatch S.I., Geoffroy J.-J., Mauriès J.-P., VandenSpiegel D. 2009b. Review of the millipede genus Eutrichodesmus Silvestri, 1910 (Diplopoda, Polydesmida, Haplodesmidae), with descriptions of new species // ZooKeys. Vol.12. P.1-46.

Golovatch S.I., Geoffroy J.-J., Mauriès J.-P., VandenSpiegel D. 2015. Review of the millipede genus Eutrichodesmus Silvestri, 1910, in China, with descriptions of new cavernicolous species (Diplopoda, Polydesmida, Haplodesmidae) // ZooKeys. Vol.505. P.1-34.

Golovatch S.I., Mikhaljova E.V., Korsós Z., Chang H.W. 2010. The millipede family Haplodesmidae (Diplopoda, Polydesmida) recorded in Taiwan for the first time, with the description of a new species // Tropical Natural History. Vol.10. No.1. P.27-36.

Responsible editor K.G. Mikhailov 